\title{
Reassessment of Fixed Assets
}

\author{
${ }^{2}$ Albana Demi, Phd. \\ 1 Lecturer at Aleksander Moisiu University, Faculty of Business, Durres, Albania \\ ${ }^{2}$ Canadian Institute of Tchnology, Head of CIRD economy, Tirana, Albania \\ shqipexhaferri@yahoo.com; demialbana@gmail.com
}

\section{Doi:10.5901/mjss.2015.v6n5p107}

\section{Abstract}

Making the economic decisions depend to a large extent on the quality and level of information that owns. The quality and the reliable information obtained from financial statements is very important for successful decision-making and the economic development of a country, for the development of financial markets, to promote the entry of foreign investments and economic stability of the country. The financial statements are prepared in accordance with International Financial Reporting Standards ("IFRS") published for the first time by the Board of the International Accounting Standards. This study aims to present information related to the valuation of assets by taking as a concrete case Durres Port Authority. Risk assessment and return of assets is the basis of quantitative distribution of assets and portfolio risk management. The economists can calculated these parameters through the observed price. These awards provide information on the value of the asset, based on valuation methods and individual analysts' expectations. In this content, to continue with the results, we need to understand how we can asses individual titles in accordinace with the market.

Keywords: Active, cash flows, risk, return, financial markets, accounting standarts, finantial statments.

\section{Introduction}

The basis for the majority of valuation techniques is a flow discounting future payments at the present time. In appreciation of securities, whether stocks, bonds or other assets, performed discounting future cash flows. In the case of bonds, have regular payments of interest and ultimate payment of principal. In terms of stock, investors should focus on company cash flows, to study increasing the value of the asset at the time. Discounting the future cash flows of an appropriate rate of interest is essential. As can be proved, relatively small changes in the interest rate can have great impact on the present value of cash flows. Most of these streams contain risk, thus discounting at an interest rate not riskioze would be inaccurate, especially for companies. The interest rate should reflect the risk of financing the activities of the company.

Miles, James, Ezzell, and John (1980) define the rate WACC (Weighted Average Cost of Capital), calculated as a weighted average of the costs of the company. Consider a company that seeks to fund a new project investment. The company plans to finance $45 \%$ of the project through bonds and $55 \%$ by issuing new shares. Buyers of bonds the company seeking a profit rate of $8 \%$, while the holders of shares require a rate of $14 \%$ to access financing scheme. WACC has requested for funding this project will be:

WACC $=0.45 \times 8 \%+0.55 \times 14 \%=11.3 \%$

Appropriate rate for discounting future monetary flows of the company is $11.3 \%$. We can conclude that for a company to fund alone and debt securities, general definition of WACC-in will be as follows.

$W A C C=W_{E} \cdot k_{E}+W_{D} \cdot k_{D}(1-t)$

Where, $W_{E}$ is the weight of the securities in the capital structure of the company, $k_{E}$ is the cost of equity capital, $W_{D}$ is the weight of debt in the capital structure, $k D$ is the cost of debt and it is the marginal tax rate. We use the marginal tax rate, because we are dealing with new funding. Term debt cost will be and the granting of the loan rate by the company, while the cost of securities of the company can be determined by several methods, for example, "Capital Asset Pricing Model. Usually, debt and assets of the company are divided into sub-components, each with their cost of capital to have a much clearer picture of the actual cost of capital of the company. For example, the shares can be divided into common and preferred. When discount flows through the WACC, we are testing whether the expected cash flows are sufficient to cover the initial investment, the sponsor's contribution to the company. In net present value (NPV, net present value) of 
new investment is equal to zero, then investors would simply cover their initial costs, nothing more (Glenn P. Jenkins, Arnold C. Harberger., 2000). Each value of NPV's greater than zero indicates that capital contributors have interest in undertaking the relevant investment, since profit is positive. Confirmed the above principle is valid for any kind of investment and financial analysts can help determine profit investment scheme. A company can be compared with an investment portfolio, so if discount and collect all possible investment projects, will find the value of the company.

\section{Methodology}

Base model using discounted cash flows (DCF) is the definition of cash flows generated by the asset in question. This problem does not exist in the case of bonds, because their payments are recognized and required only the determination of the interest rate (BANZ, Rolf W. 1981). For shares the problem is not simple. In the best case, we would like to recognize the flow of payments for each year up to infinity and then find the current value of these flows, to identify the value of the company (Govori, Fadil 2010). Obviously, it is impossible in practice, so we define an approximate value.

The first step - has to do with the definition of cash flow. Almost all the methods used are based on the balance of companies. The two most important are the direct method and indirect method. Using the direct method means sharing the company's financial activity in three parts:

- Operating Activities

- Investment Activities

- Financing Activities

For each of the above, determine a specific cash flow, gathering later to identify the total cash flow of the company. CAPM (Capital Asset Pricing Model)

Model discounted cash flow forecast is based on explicit thousands of potential characteristics of the company, many of their subjective nature. Working with these models requires a large number of resources, which can be difficult to locate, especially when dealing with existing stock portfolio and potential shares to be included (Black, Fischer, Michael C. Jensen and Myron Scholes. 1972). As asset managers, we want a consistent method of determining the price, which can be applied to any type of asset, regardless of the nature of the activity which he represents. In 1963, William Sharpe, John LINTNER and Jan mossi developed, independently, a model for determining the price of assets, called the Capital Asset Pricing Model (CAPM).

In this model the return of an asset is described completely by the combination of market return to that asset. The idea is to compensate investors for the risk necessary, but not to unnecessary risk. Required risk is the risk associated with the market (systematic risk), while unnecessary risk is associated with a specific activity (non-systematic risk). The CAPM expresses a linear relationship between asset returns and market returns, ie asset returns can be explained by a single factor, the return of the market. We have already defined the asset Beta-n as a risk assessment. In portfolio theory we are interested only in the systemic risks, because no systematic risk can be reduced or eliminated through diversification of the portfolio, adding other assets.

Below we present the CAPM model for asset $A$ is the only explanatory variable is the return of the market.

$r A, n=a_{n}+\beta_{A, n} \cdot r_{m, n}+\varepsilon_{n}$,

where; $r_{A, n}$, is the efficiency of asset $A$ at time $n, a_{n},(a l p h a)$ is a constant term of the linear relationship between market returns and asset returns, $r_{m, n}$, is the market yield at the time $n, \beta_{A, n}$ ( beta) is the slope of the linear relationship at the time $\mathrm{n}$ and $\varepsilon_{\mathrm{n}}$ is the error term.

The variance of the return of the asset $A$ is:

$\operatorname{Var}\left(r_{A, n}\right)=\operatorname{Var}\left(a_{n}+\beta_{A, n} \bullet r_{m, n}+\varepsilon_{n}\right)=\operatorname{Var}\left(a_{n}\right)+\operatorname{Var}\left(\beta_{A, n} \bullet r_{M, n}\right)+\operatorname{Var}\left(\varepsilon_{n}\right)$

Since the variance of a constant term is zero, we have:

$\operatorname{Var}\left(r_{A, n}\right)=\operatorname{Var}\left(\beta_{A, n} \cdot r_{m, n}\right)+\operatorname{Var}\left(\varepsilon_{n}\right)$

The expression above shows that the risk of an asset can be classified into systematic risk (relative to the market) and non-systematic risk (risk of waste or asset specific risk). So, we have:

$\operatorname{Var}\left(\mathrm{r}_{\mathrm{A}, \mathrm{n}}\right)=$ Systematic Risk + Risk Non-systematic

Market related risk (systematic) is inevitable and should be undertaken by all investors. The risk that is not related to the market (risk of waste) can be eliminated through diversification and, consequently, is fixed by the investors who expect a greater return. A non-riskioz asset guarantees us a non-riskioze yield rate, while a riskioz asset guarantees us a non-riskioze yield rate plus a premium for risk, caused by a systemic risk amount (not to diversifikueshëm).

As mentioned above, straight lines representing the linear relationship between asset yields $x_{r}$ and its covariance, called Curve Securities Market (Security Market Line-SML), illustrated in the figure below.

An asset with high covariance with the market, so with a high level of systemic risk, should offer a higher yield, to 
be attractive to investors. According to the CAPM equation, asset yield is proportional to the risk associated with the market (estimated by beta) and residue yields are equal to zero. Due to the initial assumption of only one explanatory variable, we observe generally a large fluctuation in the values of model parameters. Another problem relates to the selection of the market for the assessment of the equation, because there is no precise rule to do this. An intelligent solution will be the representative index where the asset belongs. Usually, R-square of these estimates is low, below $50 \%$. This low explanatory power is expected, since the model is a factorial and can not 'catch' the variation of returns across assets. If you would like to appreciate an asset with greater precision, we need to estimate a model with a larger number of factors.

\section{Research - Overview of "Auoriteti Port" Durres, JSC}

Durres Port Authority JSC (The "Company") was established as a joint stock company and was recorded on 4 December 1998, based on the decision of the Ministry of Public Economy and Privatization on 13 November 1998. Before founding date, the Company was a state enterprise. The Company's sole shareholder is the Ministry of Public Works, Transport and Telecommunications of Albania (in 2006 the Company's shareholder, the Ministry of Economy, Trade and Energy of Albania).Based on the decision of the Council of Ministers No. 596 dated 10 September 2004 and the Law no. 9130 On 8 September 2003 the company changed its status from a joint stock company in legal public entity as defined in the "Law on commercial companies". This legal transformation was made in order to improve the efficiency and profitability of the port through a course independent of the trade. The Company's main activity is the provision of port services to third parties, such as loading and unloading of cargo ships, ferry boat mooring and storage. Historically, the port of Durres has been an important artery of economic activity in Albania and the region. Port infrastructure has expanded mostly after World War II, but only after the 90 port restructured form his direction and upgraded its capabilities to meet growing commercial traffic more effectively.

The company is positioned $42 \mathrm{~km}$ from Tirana, near the town of Durres and the northern Gulf of Durres $18 \mathrm{~km}$ long. Access by road to Tirana performed through a 4-lane highway. This highway connects with Corridor VIII, the road that links the Adriatic coast to the Black Sea coast. Also has access in the north and south highway that runs in Montenegro and Greece as well as the new highway that connects with Kosovo. Durres is Albania's main port and conducts about $80 \%$ of the country's maritime trade.

Durres Port Authority Structure JSC consists of Board of Directors and Chief Executive Officer. The Board of Directors consists of seven representatives from the Ministry of Economy (1), Ministry of Transport (2), the region of Durres (1), Hall (1) and private companies related to port activity (2). These members can not be elected for a period longer than 3 years. The Director General is elected by the Board of Directors.

On 31 December 2008 the Company had hired a total of 625 employees. Company offices are in Durres, Albania. APD has achieved significant improvements with respect to the range and quality of commercial services offered by financial and technical assistance to various international institutions like the World Bank, the European Investment Bank and EBRD.

Two major strategies for growth that are planned by APD refer to:

- Transformation of the shape of the port from a port in a port services administrator soil focusing on the direction of the port. APD should act as a regulatory and monitoring agent on behalf of the Albanian state.

- Terminal the port, which includes the construction of 6 new terminals.

Law on the Port Authority considers reorganization of APD in the port administrator, in which the Port Authority provides and manages the port area (land and water) and basic infrastructure (anchor sites), while all port operations and related services provided from the private sector, subject to concessions and licenses regulated by the Port Authority Law and the Law of Concessions.

The company plans to undertake investments for 2009 with a value of $3,075,072,000 \mathrm{ALL}$, fully financed by funds portit.Investiments planned to be taken are listed in the following table. All these investments will expand the capacity of the port assets, and none of these investments is not intended to maintain the capacity of existing assets as follows:

\section{Investments}

Construction builds

Machinery and equipment

Auto mechanism

Vehicles

Computer and office equipment system
The amount of planned

$2,226,077,000$

$314,433,000$

$128,000,000$

$4,624,000$

$273,800,000$ 
Consultancy and training projects Other investments

Total
$60,777,000$

$67,359,000$

A part of planned investments in building 2010 refers to $50 \%$ of the value of berths No. 10 , totaling 800 million leks. In the above investments are not including investments for the construction of a new ferry terminal and berth No. $7 / 8$ as it is anticipated that they will be financed through loans granted by the European Investment Bank (EBI) and EBRD.

The financial statements are prepared in accordance with International Financial Reporting Standards ("IFRS") published for the first time by the Board of the International Accounting Standards. The financial information for the year ended December 31, 2008 is re-expressed by Albanian Accounting Standards IFRS. In the current year, the Company has applied IFRS for the first time. As a result it has implemented all standards and interpretations that were in effect on the date of the change, 1 January 2008. The implementing rules for the first time provided for in IFRS 1 "Application of International Financial Reporting Standards for the first time". On 1 January 2008, the date of the change, the position of the balance sheet opener IFRS is determined in accordance with IFRS 1 which requires that IFRS accounting policies applied on a retrospective basis with certain limited exceptions.

\section{Results}

These financial statements have been prepared in accordance with International Financial Reporting Standards (IFRS). However:

As a result of reporting under International Financial Reporting Standards (IFRS) JSC Durres Port Authority has decided to use IFRS 1 regarding fair value or revaluation as deemed cost. It states that:

"An entity may elect, at the date of transition to IFRS, to measure the fair value of an item of property - land, buildings, machinery and equipment and use this value as deemed cost at that date ". The company has made an assessment of the assets on 1 January 2008 and therefore this date was the date of transition to IFRS in order to be used deemed cost.

Date of change is determined by the date of the opening IFRS financial statements closer for the sake of comparison. Since 1 January 2008 was the date of the opening of this year's financial statements, the company's only chance to download the costs, is not the use of comparative information. This practice is contrary to IAS 1, which requires the presentation of comparative financial statements of at least one year. However management believes that this deviation to IFRS is suitable and is useful for the company, because:

- Items of specific nature and there is no market to provide their real value. As a result the real value of assets not necessarily meet the needs of users of financial statements and does not provide a significant benefit.

- The fair value of fixed assets is determined using valuation techniques, which are conditioned by the judgments and the accuracy of the evaluation of budgets and long-term cash flow.

\section{Conclusions}

From the revaluation results obtained conclude that the difficulty of implementing the standard number ' 5 ' continues to be evident in Albania.

Even long-term assets are recognized at historical cost and the residual value of businesses, tax reporting reason, therefore if the assets will continue to be held at historical cost or residual value then decreases the difficulty of implementing the standard number ' 5 ' and inversely.

Evaluation of assets at fair value is not practiced by businesses because the valuation at fair value is not recognized by taxes and costs, if you apply this value then would increase the difficulty of implementation, but the information would be most convenient and reliable by the users of financial information.

Liberal spirit of law enforcement does not help in the process of EU integration. The lack of penalties in the law "On Accounting and Financial Statements" is one of the reasons why standards have not been implemented in a fraction of the entities.

The business community, especially their senior leadership must understand that financial statements drawn up only to the tax office, but also for many other users.

A much more efficient solution to business awareness to enforcing Accounting Standards would be an additional change in the Law 9228, 24/04/2004 date "Accounting and Financial Statements" which deals with the establishment of appropriate penalties in cases its violation. 
Establish and operate the necessary structures professionally capable to resolve problems dealing with assessments and revaluations of assets as require standards.

\section{References}

Banz, Rolf W. 1981. "The Relationship Between Return and Market Value of Common Stocks." Journal of Financial Economics. 9:1, pp. 3-18.

Black, Fischer, Michael C. Jensen and Myron Scholes. 1972. "The Capital Asset Pricing Model: Some Empirical Tests," in Studies in the Theory of Capital Markets. Michael C. Jensen, Ed. New York: Praeger, pp. 79-121.

Glenn P. Jenkins, Arnold C. Harberger: Program on investment appraisal and management. Cost-Benefit analysis of Investment decisions, Harvard Institute for International Development, 2000.

Govori,Fadil, "Financë", Prishtinë 2010, Faqe 22-50

James A. Miles; John R. Ezzell The Journal of Financial and Quantitative Analysis, Vol. 15, No. 3. (Sep., 1980), pp. 719-730. 